\title{
Perbandingan Clustering Karyawan Berdasarkan Nilai Kinerja Dengan Algoritma K-Means Dan Fuzzy C-Means
}

\author{
Anissa Enggar Pramitasari ${ }^{* 1}$, Yessica Nataliani ${ }^{2}$ \\ ${ }^{1,2}$ Universitas Kristen Satya Wacana; Jl. Diponegoro No. 52-60, \\ Kec. Sidorejo, Kota Salatiga, Jawa Tengah 50711, (0298)321212 \\ ${ }^{3}$ Program Studi Sistem Informasi, FTI UKSW, Salatiga \\ e-mail: ${ }^{* 1} 682017064 @$ student.uksw.edu, ${ }^{2}$ yessica.nataliani@uksw.edu
}

\begin{abstract}
Abstrak
PT. XYZ adalah salah satu perusahaan dalam bidang industri pemintalan benang (tekstil). Untuk mencapai tujuan, PT. XYZ membutuhkan karyawan dengan kompetensi dan kedisiplinan yang baik. Oleh karena itu perusahaan melakukan penilaian terhadap karyawan berdasarkan nilai kinerja guna mengevaluasi kinerja karyawan untuk meningkatkan produktivitas karyawan.Untuk mempermudah mengelompokkan data nilai kinerja karyawan maka diperlukan teknik pengelompokan data. Pada penelitian ini akan menggunakan algoritma K-Means dan algoritma Fuzzy C-Means dengan mengelompokkan data kinerja menjadi 4 klaster, yakni tingkat kinerja sangat baik, tingkat kinerja baik, tingkat kinerja cukup dan tingkat kinerja kurang. Hasil dari penelitian ini menunjukkan bahwa Algoritma Fuzzy C-Means lebih baik digunakan untuk melakukan pengelompokan data nilai kinerja karyawan di PT. XYZ karena nilai akurasi bernilai mendekati $100 \%$ yaitu sebesar $76 \%$ dibandingkan dengan nilai akurasi algoritma K-Means sebesar $44 \%$.
\end{abstract}

Kata kunci — Data Mining, K-Means, Fuzzy C-Means, Perbandingan

\begin{abstract}
PT. XYZ is one of the companies in the yarn spinning (textile) industry. To achieve the goal, PT. XYZ needs employees with good competence and discipline. Therefore, the company evaluates employees based on performance values in order to evaluate employee performance to increase employee productivity. To make it easier to classify employee performance value data, data grouping techniques are needed. This research will use the K-Means algorithm and the Fuzzy C-Means algorithm by grouping the performance data into 4 clusters, namely the level of very good performance, good performance level, moderate performance level and poor performance level. The results of this study indicate that the Fuzzy C-Means Algorithm is better used to grouping data on employee performance values at PT. XYZ because the accuracy value is close to $100 \%$, which is $76 \%$ compared to the K-Means algorithm accuracy value of $44 \%$.
\end{abstract}

Keywords—Data Mining, K-Means, Fuzzy C-Mean, Comparison 


\section{PENDAHULUAN}

$\mathrm{P}$ T. XYZ adalah salah satu perusahaan dalam bidang industri pemintalan benang (tekstil) yang terletak di Jawa Tengah. PT. XYZ membutuhkan karyawan dengan kompetensi dan kedisiplinan yang baik. Oleh karena itu perusahaan melakukan penilaian terhadap karyawan berdasarkan nilai kinerja guna membantu membuat keputusan perpanjangan kontrak, kenaikan gaji, dan pemutusan hubungan kerja. Penilaian kinerja karyawan penting dilakukan oleh perusahaan dengan tujuan mengevaluasi kinerja karyawan untuk meningkatkan produktivitas karyawan. Penilaian yang digunakan saat ini kurang efisien karena masih mencetak dan menyebarkan kuesioner per bagian yang mana membutuhkan tenaga serta biaya yang tidak murah, selain itu sulit untuk menentukan siapa karyawan yang lebih tinggi nilainya karena nilai yang dihasilkan antara satu karyawan dengan karyawan lainnya memiliki kesamaan. Oleh karena itu untuk mempermudah mengelompokkan data kinerja karyawan maka diperlukan teknik pengelompokan data. Menurut Tan (2006) clustering merupakan metode untuk membagi data ke dalam beberapa kelompok berdasarkan kemiripan-kemiripan yang sudah ditentukan sebelumnya.

Penelitian ini menggunakan metode k-means dan fuzzy c-means (FCM). Metode k-means adalah metode untuk mengelompokkan data dengan sistem partisi [1], sedangkan metode FCM merupakan metode untuk mengelompokkan data yang mana derajat keanggotaannya menentukan keberadaan tiap-tiap titik data dalam suatu kelompok [2]. Manfaat dari penelitian ini yaitu mempermudah pengelompokkan data dengan nilai yang diperoleh masing-masing karyawan sehingga dapat digunakan untuk evaluasi dan membuat keputusan serta dapat mengetahui metode mana yang lebih baik digunakan untuk clustering karyawan berdasarkan nilai kinerja.

Bagian 1 berisi pendahuluan yang menjelaskan mengenai objek penelitian, permasalahan, metode yang digunakan dan manfaat. Bagian 2 berisi penelitian-penelitian terdahulu yang mengangkat topik clustering dan teori pendukung tentang algoritma clustering yaitu k-means dan FCM serta penjelasan metode yang digunakan dalam melakukan penelitian. Pada Bagian 3 berisi pembahasan mengenai hasil Clustering karyawan berdasarkan nilai kinerja di PT. XYZ menggunakan algoritma k-means dan FCM. Selanjutnya, Bagian 4 berisi kesimpulan dari pembahasan keseluruhan bagian. Pada bagian 5 berisi saran untuk penelitian selanjutnya.

\section{METODE PENELITIAN}

\subsection{Penelitian Terdahulu}

Pada penelitian sebelumnya menggunakan metode clustering yang dilakukan oleh Pelsri Ramadar N. S. tahun 2020 memberikan hasil bahwa metode FCM lebih baik digunakan dilihat dari nilai Silhouette Coefisient yang dihasilkan bernilai positif, serta hasil perhitungan Standar Deviasi metode FCM yang lebih kecil yaitu 0,091 dari pada metode k-means dengan hasil yaitu 0,094 [3].

Pada penelitian Implementasi Data Mining Impor beras menggunakan K-Means yang dilakukan sebelumnya oleh Agus Perdana Windarto pada tahun 2017 menghasilkan bahwa cluster impor tinggi sebanyak 2 negara, cluster impor menengah sebanyak 3 negara dan cluster impor rendah sebanyak 4 negara [4].

Dika Imantika pada tahun 2019 meneliti tentang pengelompokan menggunakan metode $k$ means dan Analytical Hierarchy Process (AHP) dengan hasil penelitian berupa korelasi kedua metode yang kuat, cluster dengan perangkingan anggota menggunakan metode System Usability Testing (SUS) serta menghasilkan sistem dashboard [5]. 


\subsection{Landasan Teori}

\subsubsection{Data Mining}

Data mining merupakan proses untuk mengekstraksi menggunakan teknik statistika dalam daftar data yang belum diketahui sebelumnya, tetapi sudah dipahami serta sangat berguna untuk database yang besar yang dapat membuat suatu keputusan yang sangat peting [6]. Data mining biasanya sering disebut dengan menemukan pola tersembunyi pada data atau (knowledge discovery) [7].

\subsubsection{Clustering}

Clustering merupakan proses pengelompokan objek data ke dalam dua atau lebih cluster dilihat dari kemiripannya [8]. Proses untuk mengelompokkan data ke dalam sebuah cluster mempunyai tingkat kemiripan yang tinggi dan data dengan cluster berbeda tidak memiliki kemiripan dengan objek lainnya [9]. Objek data yang memiliki karakteristik sama akan dikelompokan pada satu kelompok sedangankan untuk data yang mempunyai karakteristik berbeda akan dikelompokan pada kelompok lainnya untuk pengelompokan partisi [10].

\subsubsection{Algoritma K-Means}

Algoritma k-means adalah algoritma sederhana dengan jenis clustering data non hierarki yang dapat membagi data ke dalam beberapa kelompok. Algoritma k-means banyak digunakan karena mudah untuk diterapkan dan menggunakan waktu yang relatif singkat [10]. Algoritma k-means adalah suatu proses yang mempartisi data ke dalam beberapa kelompok dan setiap tahapan tertentu terhadap suatu objek. Algoritma k-means mempunyai aturan yakni ada beberapa kelompok yang akan dimasukan dan hanya memiliki atribut bertipe numerik [11]. Untuk algoritma k-means dijelaskan sebagai berikut :

1. Memasukkan data.

2. Menentukan jumlah klaster.

3. Mengambil data secara acak sesuai dengan jumlah klaster yang akan digunakan untuk pusat klaster (centroid).

4. Menghitung jarak antara data dengan pusat klaster dengan menggunakan persamaan di bawah ini.

$$
D_{i j}=\sqrt{\left(x_{1 j}-v_{1 j}\right)^{2}+. .+\left(x_{i j}-v_{k j}\right)^{2}}
$$

dimana:

$D_{i j}=$ jarak data ke $i$ ke pusat klaster ke $k$

$x_{i j}=$ data ke $i$, pada atribut ke $j$

$v_{k j}=$ titik pusat ke $k$, pada atribut ke $j$.

5. Menghitung pusat klaster dengan anggota klaster yang baru.

6. Jika pusat klaster tidak berubah maka proses klaster sudah selesai tetapi jika pusat klaster masih berubah maka ulangi langkah menghitung jarak pada langka ke empat sampai pusat klaster tidak berubah lagi [12].

\subsubsection{Algoritma Fuzzy C-Means (FCM)}

Algoritma FCM merupakan algoritma pengelompokan data dimana ditentukan oleh derajat keanggotaan [13]. Untuk beberapa objek data tidak mempunyai batasan pada salah satu kelas saja akan tetapi data dapat dikelompokkan berdasarkan derajat keanggotaan yakni antara 0 dan 1 yang menunjukkan keanggotaan parsial dari data tersebut [11]. Untuk algoritma FCM dapat dijelaskan sebagai berikut: 
1. Memasukan data yang akan dikelompokan $X$, berupa matriks berukuran $n \times m$ ( $n=$ jumlah data, $m=$ atribut setiap data), dimana $x_{i j}=$ data ke $i(i=1,2, \ldots, n)$ dengan atribut ke $j$ $(j=1,2, \ldots, m)$.

2. Menentukan:

- Jumlah klaster $=c$;

- Eksponen $f u z z y=w$;

- Error terkecil yang diharapkan $=\zeta$;

- Fungsi objektif awal: $P_{0}=0$;

- Iterasi awal: $t=1$;

- Bangkitkan partisi awal $\eta_{i k} ; i=1,2, \ldots, n ; k=1,2, \ldots, c$, sebagai derajat keanggotaan untuk data ke $i$ pada klaster ke- $k$.

Matriks partisi $\eta$ dan pusat klaster belum akurat sehingga kecenderungan data untuk berada pada suatu klaster juga belum akurat.

3. Menghitung pusat klaster ke $k, v_{k j}$, dimana $k=1,2, \ldots, c ; j=1,2, \ldots, m$, dengan

$v_{k j}=\frac{\sum_{i=1}^{n}\left(\left(\eta_{i k}\right)^{w} x_{i j}\right)}{\sum_{i=1}^{n}\left(\eta_{i k}\right)^{w}}$

4. Menghitung fungsi objektif pada iterasi ke $t, P_{t}$, dengan

$P_{t}=\sum_{i=1}^{n} \sum_{k=1}^{c} \sum_{j=1}^{m}\left(\eta_{i k}\right)^{w}\left(x_{i j}-v_{k j}\right)^{2}$

Syarat perulangan untuk mengetahui pusat klaster yang tepat menggunakan fungsi objektif, sehingga untuk langkah terakhir diperoleh kecenderungan data berada pada klaster yang mana.

5. Memperbarui matriks partisi, $\eta_{i k}$, dimana $i=1,2, \ldots, n ; k=1,2, \ldots, c$, dengan

$$
\eta_{i k}=\frac{\left(\sum_{j=1}^{m}\left(x_{i j}-v_{k j}\right)^{2}\right)^{\frac{-1}{w-1}}}{\sum_{d=1}^{C}\left(\sum_{j=1}^{m}\left(x_{i j}-v_{d j}\right)^{2}\right)^{\frac{-1}{w-1}}}
$$

6. Mengecek kondisi berhenti: Jika $\left(\left|P_{t}-P_{t-1}\right|<\zeta\right)$ maka akan berhenti tetapi jika tidak maka $t=t+1$ dan ulangi langkah ketiga [14].

\subsection{Metode Penelitian}

Pada penelitian ini menggunakan metode penelitian kuantitatif yang mana tahap awalnya adalah melakukan studi literatur terkait topik penelitian sebagai dasar penelitian dengan mencari beberapa sumber dari buku, jurnal, dan internet. Data di peroleh dengan melakukan wawancara kepada manager dan kepala bagian di PT. XYZ, selanjutnya melakukan pengamatan langsung dan mengambil data penilaian kinerja pada bagian produksi sejumlah 25 orang. Penilaian kinerja karyawan dilakukan PT. XYZ setahun sekali yaitu pada bulan Desember menggunakan kuesioner yang diisi oleh setiap kepala bagian. Data penilaian kinerja karyawan yang diambil meliputi kualitas kerja, kuantitas kerja, keterampilan kerja, kedisiplinan, dan tanggung jawab. Analisis data menggunakan metode clustering yaitu algoritma k-means dan algoritma FCM. Pada penelitian ini data karyawan akan dikelompokkan menjadi empat kelompok tingkatan, yaitu sangat baik, baik, cukup, dan kurang. Setelah itu, membandingkan hasil pengelompokkan data menggunakan k-, means dan FCM dengan hasil pengelompokkan data yang dilakukan oleh kepala bagian. Hasil dari perbandingan tersebut dapat memberikan kesimpulan metode mana yang lebih baik digunakan untuk clustering karyawan berdasarkan nilai kinerja. Gambar 1 merupakan alur metode penelitian yang digunakan. 


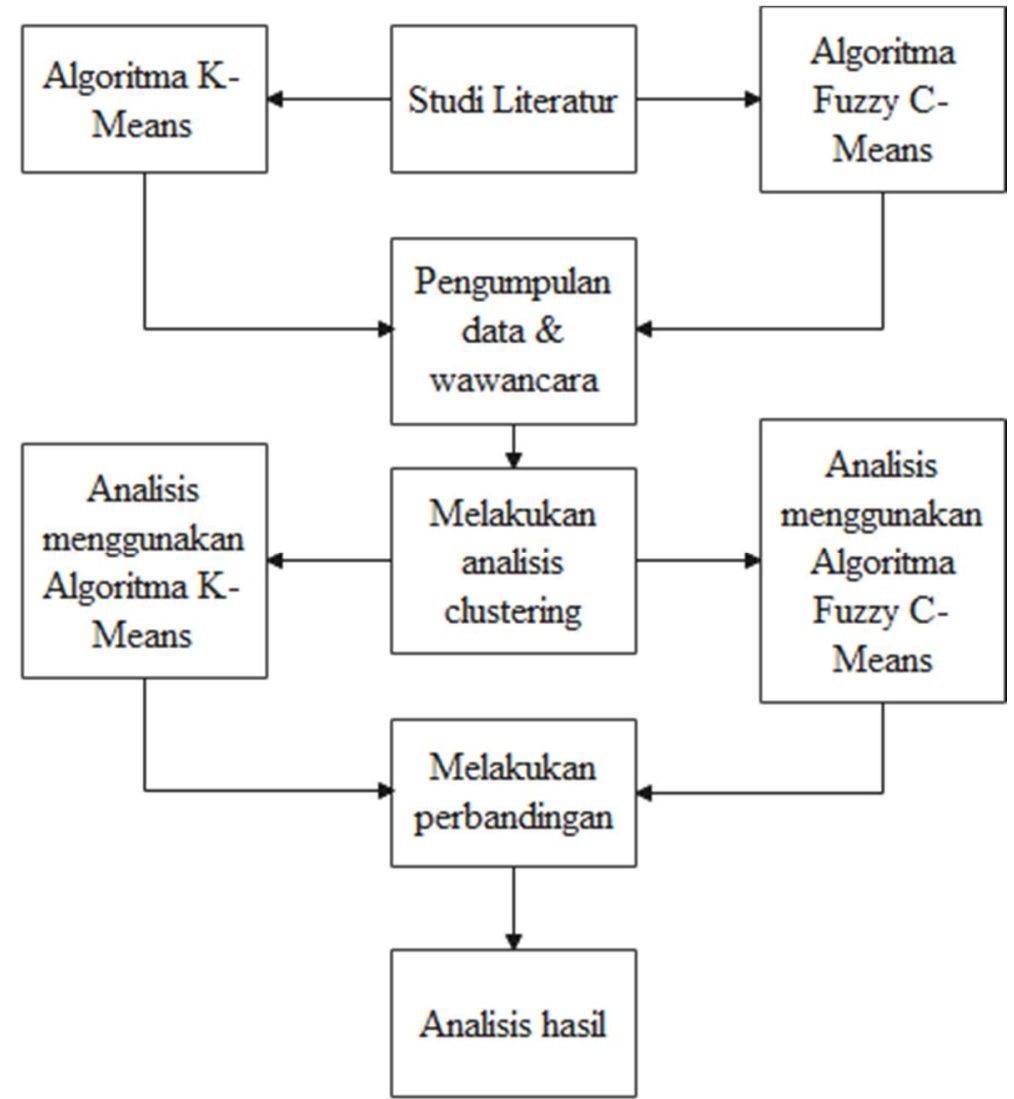

Gambar 1. Diagram Alir Metode Penelitian

\section{HASIL DAN PEMBAHASAN}

Penelitian ini akan membahas tentang perbandingan clustering menggunakan algoritma k-means dan algoritma FCM dengan mengambil 25 data nilai kinerja karyawan di PT. XYZ. Setiap algoritma akan menentukan pusat centroid setiap cluster dengan cara yang berbeda. Jumlah cluster yang akan dibuat terdiri dari empat cluster, dimana cluster satu dikategorikan tingkat kinerja sangat baik, cluster dua dikategorikan tingkat kinerja baik, cluster tiga dikategorikan tingkat kinerja cukup dan cluster empat dikategorikan tingkat kinerja kurang. Tabel 1 berisi data nilai kinerja karyawan yang digunakan.

Tabel 1. Data Nilai Kinerja Karyawan

\begin{tabular}{lccccc}
\hline \multicolumn{1}{c}{ NAMA } & KK1 & KK2 & K1 & K2 & TJ \\
\hline IRNA & 7 & 6 & 7 & 8 & 7 \\
RIYAN & 8 & 9 & 8 & 8 & 8 \\
BEDU & 7 & 7 & 7 & 8 & 7 \\
HERU & 7 & 8 & 7 & 8 & 7 \\
HARI & 7 & 7 & 8 & 8 & 7 \\
AGUNG & 7 & 7 & 8 & 8 & 7 \\
M. BIMO & 8 & 8 & 7 & 9 & 8 \\
BAGAS H. & 7 & 6 & 7 & 8 & 7 \\
ZUBAEDI & 7 & 7 & 8 & 8 & 8
\end{tabular}

Anissa, et., al [Perbandingan Clustering Karyawan Berdasarkan Nilai Kinerja Dengan Algoritma K-Means Dan Fuzzy C-Means 


\begin{tabular}{llllll} 
DANDI K. & 7 & 7 & 7 & 8 & 8 \\
LUTHFI & 8 & 7 & 7 & 8 & 7 \\
AHMAD & 8 & 8 & 7 & 8 & 7 \\
AINUN & 8 & 7 & 7 & 8 & 7 \\
ALIYA & 8 & 7 & 7 & 8 & 7 \\
DWI & 7 & 8 & 7 & 8 & 7 \\
YEMIMA & 8 & 6 & 7 & 8 & 6 \\
SHELA & 8 & 7 & 7 & 8 & 6 \\
NIA & 7 & 7 & 8 & 8 & 7 \\
LILIANA & 8 & 6 & 7 & 8 & 7 \\
KIKI A. & 7 & 7 & 7 & 8 & 7 \\
SUKIRNO & 7 & 7 & 7 & 8 & 7 \\
BUDI H. & 7 & 8 & 8 & 9 & 7 \\
NANDAR & 7 & 7 & 7 & 9 & 7 \\
HELMI & 8 & 7 & 7 & 8 & 6 \\
PARDI & 7 & 7 & 8 & 8 & 8 \\
\hline
\end{tabular}

Pada Tabel 1 terdapat lima atribut yaitu kualitas kerja (KK1), kuantitas kerja (KK2), ketrampilan (K1), kedisiplinan (K2), dan tanggung jawab (TJ) yang diambil dari data nilai kinerja karyawan PT. XYZ pada tahun 2020.

\subsection{Metode Clustering Menggunakan Algoritma K-Means}

Jumlah kelompok data pada algoritma k-means yang paling optimal ditentukan menggunakan metode Elbow. Gambar 2 menunjukkan diagram garis hasil metode Elbow. Pada gambar tersebut terdapat titik tumpul yang terbentuk di antara titik tiga dan lima. Setelah titik empat tidak ada penurunan yang signifikan, oleh karena itu jumlah kelompok berdasarkan hasil metode Elbow adalah sejumlah empat kelompok, $c=4$.

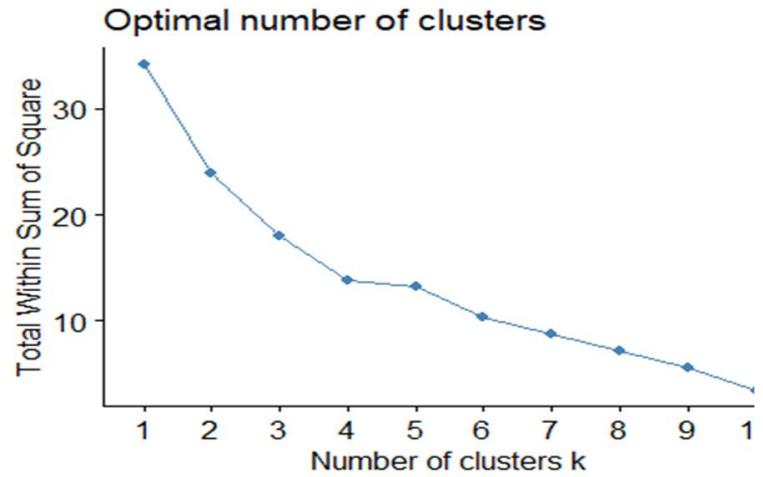

Gambar 2. Diagram Garis Hasil Metode Elbow

Data nilai kinerja karyawan diolah menggunakan algoritma k-means dimana pusat cluster akhir $(v)$ ditunjukkan pada Tabel 2, sedangkan untuk Tabel 3 merupakan output hasil clustering menggunakan algoritma k-means dari data nilai kinerja karyawan. 
Jatisi

ISSN 2407-4322

Vol. 8, No. 3, September 2021, Hal. 1119-1132 E- ISSN 2503-2933 1125

Tabel 2. Pusat Cluster

\begin{tabular}{lccccc}
\hline & KK1 & KK2 & K1 & K2 & TJ \\
\hline Cluster 1 & 8.00 & 8.16 & 8.00 & 8.33 & 7.40 \\
Cluster 2 & 7.58 & 7.00 & 7.33 & 8.14 & 7.33 \\
Cluster 3 & 7.20 & 6.71 & 7.20 & 8.00 & 7.14 \\
Cluster 4 & 7.00 & 6.70 & 7.00 & 7.58 & 6.57 \\
\hline
\end{tabular}

Tabel 3. Hasil Cluster

\begin{tabular}{lcccccc}
\hline \multicolumn{1}{c}{ NAMA } & KK1 & KK2 & K1 & K2 & TJ & Cluster \\
\hline IRNA & 7 & 6 & 7 & 8 & 7 & 4 \\
RIYAN & 8 & 9 & 8 & 8 & 8 & 1 \\
BEDU & 7 & 7 & 7 & 8 & 7 & 4 \\
HERU & 7 & 8 & 7 & 8 & 7 & 1 \\
HARI & 7 & 7 & 8 & 8 & 7 & 3 \\
AGUNG & 7 & 7 & 8 & 8 & 7 & 3 \\
M. BIMO & 8 & 8 & 7 & 9 & 8 & 1 \\
BAGAS H. & 7 & 6 & 7 & 8 & 7 & 4 \\
ZUBAEDI & 7 & 7 & 8 & 8 & 8 & 3 \\
DANDI K. & 7 & 7 & 7 & 8 & 8 & 4 \\
LUTHFI & 8 & 7 & 7 & 8 & 7 & 2 \\
AHMAD & 8 & 8 & 7 & 8 & 7 & 1 \\
AINUN & 8 & 7 & 7 & 8 & 7 & 2 \\
ALIYA & 8 & 7 & 7 & 8 & 7 & 2 \\
DWI & 7 & 8 & 7 & 8 & 7 & 1 \\
YEMIMA & 8 & 6 & 7 & 8 & 6 & 2 \\
SHELA & 8 & 7 & 7 & 8 & 6 & 2 \\
NIA & 7 & 7 & 8 & 8 & 7 & 3 \\
LILIANA & 8 & 6 & 7 & 8 & 7 & 2 \\
KIKI A. & 7 & 7 & 7 & 8 & 7 & 4 \\
SUKIRNO & 7 & 7 & 7 & 8 & 7 & 4 \\
BUDI H. & 7 & 8 & 8 & 9 & 7 & 1 \\
NANDAR & 7 & 7 & 7 & 9 & 7 & 4 \\
HELMI & 8 & 7 & 7 & 8 & 6 & 2 \\
PARDI & 7 & 7 & 8 & 8 & 8 & 3 \\
\hline & & & & & &
\end{tabular}

Selanjutnya melakukan pengelompokan karyawan dengan kategori berdasarkan output hasil clustering menggunakan algoritma k-means dari data nilai kinerja karyawan yang ditunjukkan pada Tabel 4.

Anissa, et., al [Perbandingan Clustering Karyawan Berdasarkan Nilai Kinerja Dengan Algoritma K-Means Dan Fuzzy C-Means 
Tabel 4. Pengelompokan Karyawan

\begin{tabular}{|c|c|c|}
\hline & KATEGORI & NAMA KARYAWAN \\
\hline \multirow[t]{6}{*}{ Cluster 1} & Sangat baik & BUDI H. \\
\hline & & LUTHFI \\
\hline & & ALIYA \\
\hline & & RIYAN \\
\hline & & ZUBAEDI \\
\hline & & DWI \\
\hline \multirow[t]{7}{*}{ Cluster 2} & Baik & HELMI \\
\hline & & HARI \\
\hline & & AGUNG \\
\hline & & NIA \\
\hline & & IRNA \\
\hline & & HERU \\
\hline & & SUKIRNO \\
\hline \multirow[t]{5}{*}{ Cluster 3} & Cukup & AHMAD \\
\hline & & AINUN \\
\hline & & SHELA \\
\hline & & BEDU \\
\hline & & PARDI \\
\hline \multirow[t]{6}{*}{ Cluster 4} & Kurang & M. BIMO \\
\hline & & NANDAR \\
\hline & & YEMIMA \\
\hline & & LILIANA \\
\hline & & BAGAS H. \\
\hline & & $\begin{array}{l}\text { DANDI K. } \\
\text { KIKI A. }\end{array}$ \\
\hline
\end{tabular}

Tabel 4 menunjukkan pembagian empat cluster untuk data nilai kinerja karyawan menggunakan algoritma k-means, dimana jumlah anggota cluster satu dengan kategori sangat baik sebanyak tiga anggota, cluster dua dengan kategori baik sebanyak delapan anggota, cluster tiga dengan kategori cukup sebanyak enam anggota, dan cluster empat dengan kategori kurang sebanyak delapan anggota. Pada Gambar 3 merupakan hasil diagram cluster plot, bisa dilihat bahwa hasil cluster plot dari empat cluster pada gambar garis saling menimpa, maka bisa dikatakan cluster belum ideal. Cluster dikatakan ideal jika garis tidak saling menimpa. 

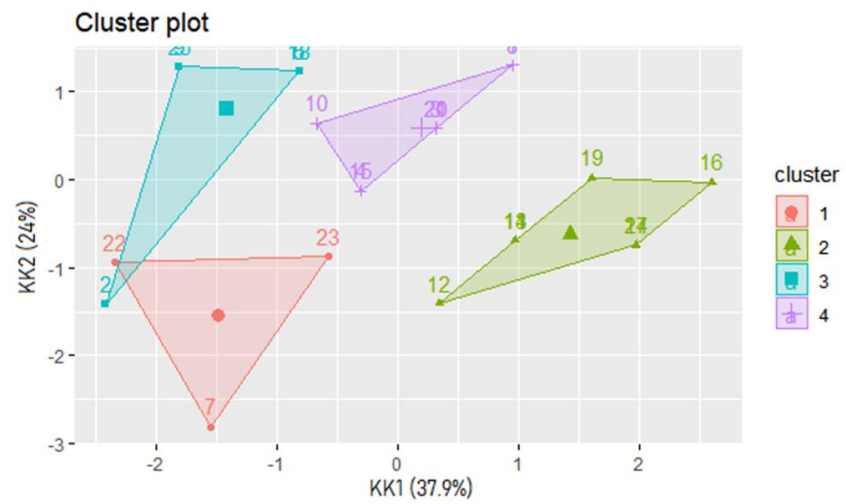

Gambar 3. Diagram Cluster Plot

3.2 Metode Clustering Menggunakan Algoritma FCM

Data nilai kinerja karyawan diolah menggunakan FCM. Hasil matriks partisi keanggotaan akhir dapat dilihat pada Tabel 5, sedangkan untuk pusat cluster akhir $(v)$ ditunjukkan pada Tabel 6.

Tabel 5. Matriks Partisi Keanggotaan

\begin{tabular}{lcccc}
\hline \multicolumn{1}{c}{ NAMA } & Cluster 1 & Cluster 2 & Cluster 3 & Cluster 4 \\
\hline M. BIMO & 0.47 & 0.09 & 0.20 & 0.22 \\
BUDI H. & 0.16 & 0.44 & 0.21 & 0.17 \\
NANDAR & 0.93 & 0.01 & 0.02 & 0.02 \\
LUTHFI & 0.15 & 0.65 & 0.10 & 0.08 \\
AHMAD & 0.04 & 0.02 & 0.90 & 0.02 \\
AINUN & 0.04 & 0.02 & 0.90 & 0.02 \\
ALIYA & 0.18 & 0.43 & 0.17 & 0.20 \\
YEMIMA & 0.47 & 0.09 & 0.20 & 0.22 \\
SHELA & 0.19 & 0.15 & 0.54 & 0.11 \\
LILIANA & 0.38 & 0.20 & 0.24 & 0.15 \\
HELMI & 0.05 & 0.03 & 0.02 & 0.89 \\
RIYAN & 0.13 & 0.54 & 0.10 & 0.21 \\
HARI & 0.05 & 0.03 & 0.02 & 0.89 \\
AGUNG & 0.05 & 0.03 & 0.02 & 0.89 \\
ZUBAEDI & 0.15 & 0.65 & 0.10 & 0.08 \\
NIA & 0.25 & 0.11 & 0.16 & 0.46 \\
IRNA & 0.19 & 0.12 & 0.11 & 0.55 \\
BEDU & 0.04 & 0.02 & 0.90 & 0.02 \\
HERU & 0.25 & 0.09 & 0.14 & 0.49 \\
BAGAS H. & 0.93 & 0.01 & 0.02 & 0.02 \\
DANDI K. & 0.93 & 0.01 & 0.02 & 0.02 \\
DWI & 0.18 & 0.37 & 0.29 & 0.13 \\
KIKI A. & 0.40 & 0.19 & 0.20 & 0.19
\end{tabular}

Anissa, et., al [Perbandingan Clustering Karyawan Berdasarkan Nilai Kinerja Dengan Algoritma K-Means Dan Fuzzy C-Means 


\begin{tabular}{lllll} 
SUKIRNO & 0.19 & 0.12 & 0.11 & 0.55 \\
PARDI & 0.19 & 0.15 & 0.54 & 0.11 \\
\hline
\end{tabular}

Tabel 6. Pusat Cluster

\begin{tabular}{lccccc}
\hline & KK1 & KK2 & K1 & K2 & TJ \\
\hline Cluster 1 & 7.94 & 7.97 & 7.90 & 8.19 & 7.22 \\
Cluster 2 & 7.39 & 7.03 & 7.20 & 8.06 & 7.19 \\
Cluster 3 & 7.07 & 6.89 & 7.03 & 8.04 & 7.03 \\
Cluster 4 & 7.04 & 6.80 & 7.01 & 8.02 & 6.81 \\
\hline
\end{tabular}

Selanjutnya dilakukan pengelompokan karyawan dengan kategori berdasarkan output hasil clustering menggunakan algoritma FCM dari data nilai kinerja karyawan yang ditunjukkan pada Tabel 7.

Tabel 7. Pengelompokan Karyawan

\begin{tabular}{|c|c|c|}
\hline & KATEGORI & NAMA KARYAWAN \\
\hline \multirow[t]{7}{*}{ Cluster 1} & Sangat baik & M. BIMO \\
\hline & & NANDAR \\
\hline & & YEMIMA \\
\hline & & LILIANA \\
\hline & & BAGAS H. \\
\hline & & DANDI K. \\
\hline & & KIKI A. \\
\hline \multirow[t]{6}{*}{ Cluster 2} & Baik & BUDI $\mathrm{H}$. \\
\hline & & LUTHFI \\
\hline & & ALIYA \\
\hline & & RIYAN \\
\hline & & ZUBAEDI \\
\hline & & DWI \\
\hline \multirow[t]{6}{*}{ Cluster 3} & Cukup & AHMAD \\
\hline & & AINUN \\
\hline & & SHELA \\
\hline & & BEDU \\
\hline & & PARDI \\
\hline & & HELMI \\
\hline \multirow[t]{6}{*}{ Cluster 4} & Kurang & HARI \\
\hline & & AGUNG \\
\hline & & NIA \\
\hline & & IRNA \\
\hline & & HERU \\
\hline & & SUKIRNO \\
\hline
\end{tabular}

Anissa, et., al [Perbandingan Clustering Karyawan Berdasarkan Nilai Kinerja Dengan Algoritma K-Means Dan Fuzzy C-Means 
Tabel 7 menunjukkan pembagian empat cluster untuk data nilai kinerja karyawan menggunakan FCM, dimana jumlah anggota cluster satu dengan kategori sangat baik sebanyak tujuh anggota, cluster dua dengan kategori baik sebanyak enam anggota, cluster tiga dengan kategori cukup sebanyak enam anggota, dan cluster empat dengan kategori kurang sebanyak enam anggota. Pada Gambar 4 merupakan hasil diagram cluster plot, bisa dilihat bahwa hasil cluster plot dari empat cluster pada gambar garis saling menimpa, maka bisa dikatakan cluster belum ideal. Cluster dikatakan ideal jika garis tidak saling menimpa.

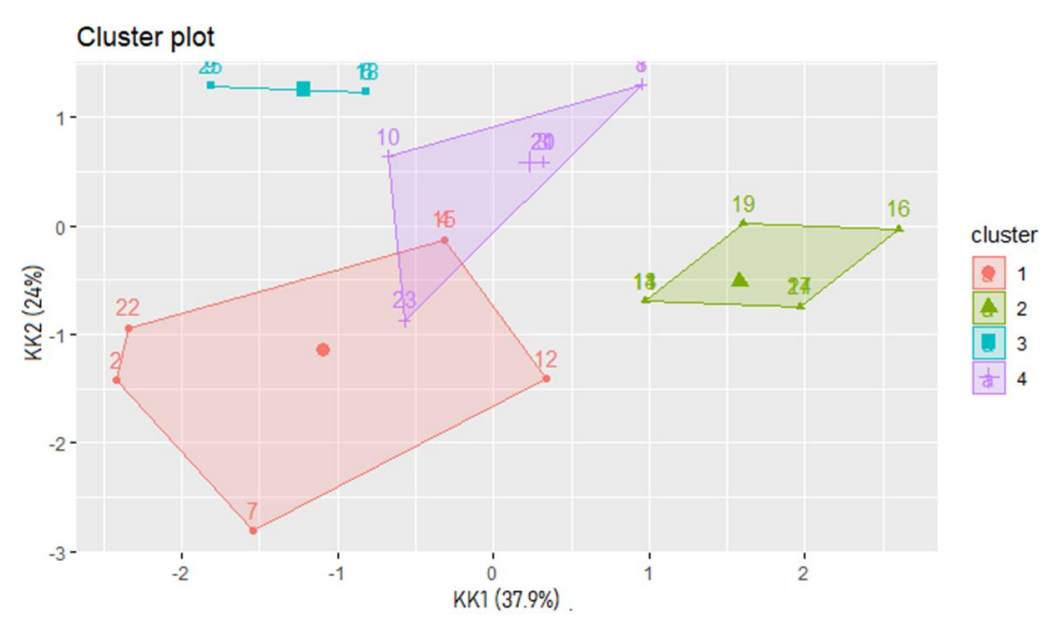

Gambar 4. Diagram Cluster Plot

\subsection{Hasil Pengujian}

Hasil pengujian diperoleh dengan membandingkan hasil pengelompokan karyawan dari kepala bagian dengan hasil pengelompokan karyawan menggunakan algoritma k-means dan algoritma FCM. Adapun hasil perbandingan clustering tersebut ditunjukkan pada Tabel 8.

Tabel 8. Perbandingan Hasil Clustering

\begin{tabular}{|l|c|c|c|}
\hline NAMA KARYAWAN & HASIL KABAG & HASIL K-MEANS & HASIL FCM \\
\hline IRNA & (4)Kurang & (2)Baik & (4)Kurang \\
\hline RIYAN & (2)Baik & (1)Sangat Baik & (2)Baik \\
\hline BEDU & (3)Cukup & (3)Cukup & (3)Cukup \\
\hline HERU & (4)Kurang & (2)Baik & (4)Kurang \\
\hline HARI & (2)Baik & (2)Baik & (4)Kurang \\
\hline AGUNG & (2)Baik & (2)Baik & (4)Kurang \\
\hline M. BIMO & (1)Sangat Baik & (4)Kurang & (1)Sangat Baik \\
\hline BAGAS H. & (1)Sangat Baik & (4)Kurang & (1)Sangat Baik \\
\hline ZUBAEDI & (2)Baik & (1)Sangat Baik & (2)Baik \\
\hline DANDI K. & (1)Sangat Baik & (4)Kurang & (1)Sangat Baik \\
\hline LUTHFI & (2)Baik & (1)Sangat Baik & (2)Baik \\
\hline AHMAD & (3)Cukup & (3)Cukup & (3)Cukup \\
\hline
\end{tabular}




\begin{tabular}{|c|c|c|c|}
\hline AINUN & (3)Cukup & (3)Cukup & (3)Cukup \\
\hline ALIYA & (2)Baik & (1)Sangat Baik & (2)Baik \\
\hline DWI & (1)Sangat Baik & (1)Sangat Baik & (2)Baik \\
\hline YEMIMA & (1)Sangat Baik & (4)Kurang & (1)Sangat Baik \\
\hline SHELA & (3)Cukup & (3)Cukup & (3)Cukup \\
\hline NIA & (4)Kurang & (2)Baik & (4)Kurang \\
\hline$\overline{\text { LILIANA }}$ & (1)Sangat Baik & (4)Kurang & (1)Sangat Baik \\
\hline KIKI A. & (4)Kurang & (4)Kurang & (1)Sangat Baik \\
\hline SUKIRNO & (4)Kurang & (2)Baik & (4)Kurang \\
\hline BUDI H. & (1)Sangat Baik & (1)Sangat Baik & (2)Baik \\
\hline NANDAR & (1)Sangat Baik & (4)Kurang & (1)Sangat Baik \\
\hline HELMI & (2)Baik & (2)Baik & (3)Cukup \\
\hline PARDI & (3)Cukup & (3)Cukup & (3)Cukup \\
\hline \multicolumn{2}{|c|}{ Jumlah Salah } & 14 & 6 \\
\hline \multicolumn{2}{|c|}{ Jumlah Benar } & 11 & 19 \\
\hline \multicolumn{2}{|c|}{ Akurasi } & $\frac{11}{25} \times 100 \%=44 \%$ & $\frac{19}{25} \times 100 \%=76 \%$ \\
\hline
\end{tabular}

Pada Tabel 8 Hasil pengelompokan karyawan dari kepala bagian bersifat subjektif karena tidak ada standar yang jelas untuk melakukan penilaian sehingga tidak sesuai dengan data penilaian kinerja karyawan yang berupa angka. Dari hasil perbandingan dapat diketahui bahwa hasil akurasi menggunakan algoritma FCM lebih tinggi yaitu sebesar 76\%, dibandingkan dengan hasil akurasi menggunakan algoritma k-means yaitu sebesar $44 \%$.

\section{KESIMPULAN}

Menurut dari hasil analisis yang sudah diperoleh dapat disimpulkan bahwa pengelompokan karyawan dari kepala bagian tidak sesuai dengan data penilaian kinerja karyawan yang berupa angka. Hasil pengelompokan dari data nilai kinerja karyawan menggunakan algoritma k-means dengan algoritma FCM berbeda. Dari hasil diagram cluster plot, pengelompokkan algoritma k-means dan algoritma FCM belum ideal. Jika dilihat dari hasil akurasi, algoritma FCM memperoleh tingkat akurasi yang lebih baik dengan hasil sebesar 76\% dibandingkan dengan algoritma k-means dengan nilai akurasi sebesar 44\%. Dari kedua algoritma tersebut yang lebih baik digunakan adalah algoritma FCM.

\section{SARAN}

Penelitian ini bisa dikembangkan lagi dengan melakukan perbandingan beberapa algoritma yang lain sehingga diharapkan dapat terlihat algoritma mana yang paling cocok 
digunakan untuk clustering data nilai kinerja karyawan. Selain itu dapat menambah jumlah atribut untuk penilaian kinerja karyawan.

\section{DAFTAR PUSTAKA}

[1] S. Setiawan. 2019, "Analisis Cluster Menggunakan Algoritma K-Means Untuk Mengetahui Kemampuan Pegawai Dibidang IT pada CV. Roxed Ltd,” J. Pelita Inform., Vol. 18, pp. 80-86, [Online]. Available: https://ejurnal.stmikbudidarma.ac.id/index.php/pelita/article/view/1142.

[2] P. E. Mas`udia, F. Arinie, and L. D. Mustafa. 2018, “Clustering Data Remunerasi Dosen Untuk Penilaian Kinerja Menggunakan Fuzzy c-Means,” J. RESTI (Rekayasa Sist. dan Teknol. Informasi), Vol. 2, No. 1, pp. 288-294, doi: 10.29207/resti.v2i1.97.

[3] P. R. N. Saputra and A. Chusyairi, 2020, "Perbandingan Metode Clustering Dalam Pengelompokan Data Puskesmas,” J. RESTI (Rekayasa Sist. dan Teknol. Informasi), Vol. 4, No. 6, pp. 1077 - 1084.

[4] A. P. Windarto. 2017, "Implementation of Data Mining on Rice Imports by Major Country of Origin Using Algorithm Using K-Means Clustering Method,” Int. J. Artif. Intell. Res., vol. 1, no. 2, p. 26, doi: 10.29099/ijair.v1i2.17.

[5] D. Imantika et al. 2019, "Penerapan Metode K-Means Clustering dan Analytical Hierarchy Process (AHP) Untuk Pengelompokan Kinerja Guru dan Karyawan pada SMA Brawijaya Smart School," J. Pengemb. Teknol. Inf. dan Ilmu Komput. J-PTIIK, vol. 3, no. 8, pp. 7382-7390, [Online]. Available: http://j-ptiik.ub.ac.id/index.php/jptiik/article/view/5958.

[6] S. A. Rahmah. 2020, "Klasterisasi Pola Penjualan Pestisida Menggunakan Metode KMeans Clustering (Studi Kasus di Toko Juanda Tani Kecamatan Hutabayu Raja )," J. Inf. Technol. Res., Vol. 1, No. 1, pp. 1-5,

[7] I. K. Juni Arta, G. Indrawan, and G. R. Dantes, "Data Mining Rekomendasi Calon Mahasiswa Berprestasi di STMIK Denpasar Menggunakan Metode Technique for Others Reference by Similarity to Ideal Solution," JST (Jurnal Sains dan Teknol., Vol. 5, No. 2, p. 792, 2017, doi: 10.23887/jst-undiksha.v5i2.8549.

[8] R. Syarif, M. T. Furqon, and S. Adinugroho. 2018, "Perbandingan Algoritme K-Means Dengan Algoritme Fuzzy C Means ( FCM ) Dalam Clustering Moda Transportasi Berbasis GPS," J. Pengemb. Teknol. Inf. dan Ilmu Komput. Univ. Brawijaya, Vol. 2, No. 10, pp. 4107-4115, [Online]. Available: http://j-ptiik.ub.ac.id/index.php/jptiik/article/view/2852.

[9] M. Simanjuntak and Dkk. 2018, "Penerapan Data Mining Pengelompokan Kejahatan Elektronik Sesuai UU ITE Dengan Menggunakan Metode Clustering,” J. Mahajana Inf., Vol. 3, No. 2, p. 3. 
[10] G. Gustientiedina, M. H. Adiya, and Y. Desnelita, "Penerapan Algoritma K-Means Untuk Clustering Data Obat-Obatan,” J. Nas. Teknol. dan Sist. Inf., Vol. 5, No. 1, pp. 17-24, 2019, doi: 10.25077/teknosi.v5i1.2019.17-24.

[11] N. Agustina and P. Prihandoko. 2018, "Perbandingan Algoritma K-Means dengan Fuzzy C_Means Untuk Clustering Tingkat Kedisiplinan Kinerja Karyawan (Studi Kasus: Sekolah Tinggi Teknologi Bandung)," J. RESTI (Rekayasa Sist. dan Teknol. Informasi), Vol. 2, No. 3, pp. 621-626, doi: 10.29207/resti.v2i3.492.

[12] D. M. Santiaji. 2017, “Simki-Techsain Vol. 01 No. 01 Tahun 2017 ISSN : 0302-0117," Simki-Techsin, Vol. 01, No. 01, pp. 1-7.

[13] Wikarno, R. Malani, and B. Suprapty. 2018, "Perbandingan Metode K-Means dan Fuzzy C-Means Untuk Pengelompokan Pegawai Berdasarkan Nilai Kinerja dan Tingkat Kedisiplinan Pegawai,” Pros. Semin. Ilmu Komput. dan Teknol. Inf., Vol. 3, No. 1, pp. $45-52$,

[14] M. Martin and Y. Nataliani. 2021, "Klasterisasi Kinerja Karyawan Menggunakan Algoritma Fuzzy C-Means," Aiti, Vol. 17, No. 2, pp. 118-129, doi: 10.24246/aiti.v17i2.118-129. 